\title{
A TRAVÉS DE LA PANTALLA: JUEGOS DE MIRADAS Y TRANSGRESIÓN EN “NO PERDURA” DE JOSÉ EMILIO PACHECO
}

\begin{abstract}
We don't know space. We do not see it, we do not hear it, we do not feel it. We are standing in the middle of it, we ourselves are part of it, but we know nothing about it... Space remains inscrutable, a miracle ${ }^{1}$.
\end{abstract}

La obra artística abre un espacio diferente del cotidiano, un espacio "otro" que no puede ni debe confundirse con el espacio vital, so riesgo de que se desvirtúe lo que tiene de específico y ficticio lo artístico. De ahí que se introduzca una frontera material que delimita el espacio artístico del cotidiano: marco del cuadro, diferenciación entre escenario y público, creación en suma de las condiciones de un espectáculo $^{2}$. El cuento "No perdura" de José Emilio Pacheco (1939-2014), texto que abre la cuarta sección del volumen La sangre de Medusa y otros cuentos marginales $(1990)^{3}$, es el relato de la superación de ese límite. En una sala de cine, en 1961, Ernesto y Claudia están viendo una película de horror rodada en 1930, en la cual un vampiro acaba matando al protagonista. A pesar de cierta familiaridad que Ernesto advierte entre el ambiente de la película y el de su casa, mantiene una actitud irónica y destacada. Cuando vuelve a su casa, sin embargo, le espera un acontecimiento imprevisto: de sujeto que mira las escenas en la pantalla, se descubre imagen mirada dentro de la misma.

1 M.C. Escher, Escher on Escher: Exploring the Infinite, Harry N. Abrams, New York, 1989, p. 135.

${ }^{2}$ Cf. Eugenio Trías, Filosofía del futuro, Ariel, Barcelona, 1983, p. 111.

3 José Emilio Pacheco, "No perdura", en La sangre de Medusa y otros textos marginales, Era, México, 1990, pp. 85-87. La única referencia al texto en examen se encuentra en un artículo de José Luis Martínez Morales dedicado a la presencia del mito de los vampiros en la literatura mexicana del siglo xx (" ¿Vampiros mexicanos o vampiros en México?”, LEJANA. Revista Crítica de Narrativa Breve, 2012, núm. 4, en http://lejana.elte.hu. 
El relato se inserta en la indagación sobre la borrosidad de las fronteras -entre "realidad" y ficción, así como espaciales y temporales-, ampliamente explorada por José Emilio Pacheco a lo largo de su producción narrativa. Baste con citar los cuentos "Civilización y barbarie", contenido en el volumen $\mathrm{El}$ viento distante (1963), "La fiesta brava", "Cuando salí de La Habana válgame Dios", ambos recopilados en El principio del placer (1972), y "Dentro de una esmeralda", perteneciente a La sangre de Medusa y otros cuentos marginales (1990), con los cuales "No perdura" establece una relación intertextual. En el primero, se pone en escena el trastocamiento y la fusión de tres planos temporales distintos, ya que el protagonista, Mr. Waugh, atrincherado en su hogar por miedo a las protestas de los negros en los años sesenta del siglo $\mathrm{xx}$, se descubre acosado por los jinetes apaches de la película que acaba de ver en la televisión y, paralelamente, su hijo perece víctima de una trampa vietnamita. El mecanismo literario de fusión de niveles ontológicos distintos se perfecciona en el segundo cuento, en el cual el protagonista, Andrés Quintana, es autor de una narración titulada "La fiesta brava", contenida en el homónimo cuento de Pacheco, a la vez que ente ficticio de la trama global. Las dos ficciones acaban sobreponiéndose, porque Quintana es víctima de la trampa que él mismo inventó para su personaje de ficción ${ }^{4}$.

En el tercer texto citado, "Cuando salí de La Habana válgame Dios”, en cambio, tres días se convierten en cien años para los protagonistas, pues un velero zarpado de la capital cubana en 1912 llega al puerto de Veracruz en 2012. Finalmente, en "Dentro de una esmeralda", el protagonista admira una esmeralda y descubre en su interior a una mujer y, tras una desesperada tentativa por liberarla, acaba ocupando el lugar de ella dentro de la prisión de piedra.

En la misma línea, la escritura de "No perdura" se construye sobre la puesta en duda del concepto de límite, ontológico y estético, entendido como producto cultural establecido, a través de la transgresión de la frontera entre espacio artístico y cotidiano. Es conocida la acti-

${ }^{4}$ Para una profundización del análisis de "Civilización y barbarie" y "La fiesta brava", véanse Rafael Olea Franco, "De la ansiedad de influencia: Borges en Pacheco", en José Emilio Pacheco. Perspectivas críticas, coords. P. Popovik Karic y F. Chávez Pérez, Tecnológico de Monterrey-Siglo XXI, Monterrey, 2006, pp. 30-52; Cynthia Duncan, "The Fantastic as a Vehicle of Social Criticism in José Emilio Pacheco's «La fiesta brava»", Chasqui: Revista de Literatura Latinoamericana, 1985, núms. 2/3, pp. 3-13; y Barbara Bockus Aponte, "José Emilio Pacheco, cuentista", en La hoguera y el viento. José Emilio Pacheco ante la crítica, ed. H. Verani, Universidad Autónoma Metropolitana, México, 1993, pp. 131-149. Para una visión más general de los mecanismos fantásticos en la narrativa breve de José Emilio Pacheco, véase el estudio de Hugo Verani, "José Emilio Pacheco: umbrales de lo fantástico", en el ya citado José Emilio Pacheco. Perspectivas críticas, pp. 11-29. 
vidad de guionista que caracteriza la carrera del autor ${ }^{5}$, por lo cual en este estudio se empezará considerando la interacción entre lenguaje fílmico y literario en el texto, para poner de relieve la deconstrucción del primero por parte del segundo ${ }^{6}$. A partir de ahí, se examinará el juego de perspectivas y puntos de vista, y cómo dicho juego permite la superación de los límites temporal y espacial en la pantalla cinematográfica ${ }^{7}$. El paso siguiente es el análisis de las complejas dinámicas de saber vinculadas al poder de la mirada que se construyen en el cuento $^{8}$, dinámicas que, una vez desentrañadas, permiten acceder a una interpretación del cuento en clave simbólica como espacio de subversión y ruptura de los conceptos monolíticos de realidad y sujeto, y como modelo de conflicto que problematiza y vuelve a plantear la idea de representación.

\section{DEL “LADO DE ACÁ”}

Como es sabido, la representación registra al mismo tiempo que efectúa una clasificación; al representar el mundo, la palabra y la imagen lo (re)organizan. El límite es clave en ese proceso, ya que es el requisito de la inteligibilidad del mundo; sin el límite el orden, condición

${ }^{5}$ El castillo de la pureza (1972), El santo oficio (1974), Foztrot (1976), El lugar sin límites (1978) y Mariana, Mariana (1987).

${ }^{6}$ Con respecto al análisis del lenguaje fílmico en el texto y su interacción con el literario, el planteamiento teórico se funda en particular en los estudios de GiLles Deleuze, La imagen-movimieto. Estudios sobre cine 1, Paidós, Barcelona, 1984 y La imagentiempo. Estudios sobre cine 2, Paidós, Barcelona, 1987; Erwin Panofsky, "Stile e mezzo nel cinema”, en Cinema E Film, 1968, núms. 5/6, 5-14; Mario Pezzella, Estetica del cinema, Il Mulino, Bologna, 1996 y JEAn-Louis Comolli, Ver y poder. La inocencia perdida: cine, televisión, ficción, documental, Nueva Librería, Buenos Aires, 2007.

7 Podría observarse que un procedimiento parecido al que utiliza José Emilio Pacheco fue recurso de Horacio Quiroga en los relatos "El espectro", recopilado en El desierto (1924), y "El vampiro", contenido en el volumen Más allá (1935). En el primero, Guillermo Grant y su amante Enid son observados y luego asediados por "el espectro cinematográfico" -un ser de ilusión óptica, un fantasma producido por la invención técnica- de un actor famoso y ex marido de Enid, desde la imagen de una película proyectada en la pantalla. En el segundo, en cambio, una bella actriz abandona la película y en condición de espectro se enamora de un extraño espectador. Sin embargo, en los cuentos citados el movimiento que se pone en escena dentro del relato es unívoco, de la pantalla hacia el personaje-espectador; en "No perdura", en cambio, Pacheco rompe y ensancha dicha univocidad, añadiendo otro movimiento al antes descrito, es decir, una reciprocidad de la mirada, de la platea a la pantalla.

${ }^{8}$ El estudio de las líneas de poder y saber vinculadas a la mirada se contruye sobre la fenomenología de la visión y de percepción, en particular a través del trabajo de Maurice Merleau Ponty, El mundo de la percepción: siete conferencias, F.C.E., Buenos Aires, 2002, y los estudios de Jacques Lacan, Los cuatro conceptos fundamentales del psicoanálisis, Paidós, Buenos Aires, 1995, y "El estadio del espejo”, en Escritos, Siglo XXI, Buenos Aires, 2003, pp. 86-93. 
de la vida opuesta a la aridez ontológica y gnoseológica del caos, sería imposible. La certeza del límite coincide, por lo tanto, con la certeza de lo real. La insistencia filosófica en este concepto responde al impulso de hacer inteligible el mundo, articulando la dialéctica entre la sustancia de lo real y sus formas de representación. Como recuerda Eugenio Trías, el límite del mundo es el límite que define lo que pueda conocerse o decirse, es decir, representarse, y lo que no puede ser en el mundo se dice imposible por no representable ${ }^{9}$. Los confines de la representación se trazan entonces sobre los del conocimiento.

De este concepto se deriva que, si la mirada es instrumento hermenéutico privilegiado, el límite de la representación coincide con el de la mirada. El relato en examen se desarrolla en su comienzo precisamente sobre el ejercicio de la soberanía de la mirada del protagonista, espectador enterado, dentro de los límites espaciales de la sala de cine.

El relato se divide en dos partes, separadas por un hiato espacial y tres secuencias. Se abre in medias res con un close up sobre la mano de Claudia que agarra la de Ernesto: "La mano de Claudia se cerró con más fuerza en su mano"10. Esta imagen anticipa el contraste que dominará a lo largo de toda la primera parte entre el horror que siente Claudia ante las escenas de la película y la sorna de Ernesto ante las mismas. El protagonista demostrará conocer muy bien los recursos del cine, lo que brinda cierta superioridad a su mirada y le permite mantener una actitud destacada con respecto a lo que ocurre en la pantalla, a pesar de cierta familiaridad que el hombre percibe ante el ambiente reproducido en la película y que será decisiva en la segunda parte.

En la primera secuencia, la focalización oscila constantemente entre lo interno del personaje Ernesto y lo externo, puesto que la narración en tercera persona se entreteje con las reflexiones del protagonista sobre los trucos cinematográficos de la película que está viendo. En el texto se lee:

Ni siquiera está bien hecha... La actuación ya resulta muy anticuada. En el fondo es involuntariamente cómica. No me explico por qué no se ríe el público. Pero la mano de Claudia llenaba de sudor la palma de la mano de Ernesto, mientras en un campanario de utilería, en un estudio de filmación destruido años después por las bombas aliadas, suenan las doce de la noche en un reloj que ya no existe.

En el párrafo siguiente, la mirada de Ernesto se funde y se confunde con la reflexión meta-cinematográfica del narrador:

9 Cf. Eugenio Trías, La razón fronteriza, Destino, Barcelona, 1999.

${ }^{10}$ Las referencias a "No perdura", provienen de la edición citada de La sangre de Medusa y otros textos marginales, por lo que, en adelante, sólo doy el número de página entre paréntesis cuando sea pertinente. 
En ese mundo de celuloide próximo a deshacerse por la acción corrosiva de los nitratos la ventana se abre, vuela un falso murciélago que sostiene un hilo finísimo y, por obra del montaje, se transforma en vampiro. Es decir, en un hombre pálido y verdoso -el blanco y negro de la película no autoriza esta precisión... El intérprete se vuelve hacia la cámara. Lo observan el director, el camarógrafo, la script-girl, todo el equipo (p. 85).

De este modo, las técnicas de montaje y reproducción de las imágenes se hacen "visibles" al lector en la acción misma de su recepción por parte del personaje y a medida que el cuento avanza. En esta línea, otro aspecto importante del lenguaje cinematográfico que el cuento utiliza y reelabora es la idea según la cual el montaje cinematográfico adquiere los rasgos de figura de la muerte, en cuanto transforma de manera incesante el devenir presente en la fijeza del pasado; la muerte como el montaje es un corte, cut, que interrumpe el devenir y petrifica el ser.

La descripción de las escenas de filmación a través del filtro de la conciencia del personaje, permite desenmascarar, y tal vez exorcizar, la pulsión de muerte como una de las características intrínsecas del cine. Al mismo tiempo, sin embargo, a nivel formal, el hiato espacial que separa la primera y la segunda parte muestra ese "corte mortal"11 y remite a la muerte como una de las intenciones subterráneas del relato, y que constituirá una anticipación del trastocamiento que se dará en el segundo apartado y en el desenlace.

Como es sabido, el cine es capaz de reproducir un "efecto de realidad" superior con respecto a las otras formas de arte; sin embargo, el cuento remite también a uno de los límites insuperables de su técnica, es decir, la distancia temporal entre el momento de la filmación y el de la visión. Una vez más ese límite es delatado por la mirada crítica de Ernesto. En el texto se lee: "Pero qué absurdo compartir en 1961 la sugestión de un público idiota al que espantan los trucos de una película filmada en los años treinta" (p. 85). Dicha distancia temporal es un residuo del carácter tradicional de la imagen; de hecho, desde que el hombre ha empezado a crear imágenes, entre la imagen y el objeto que representa hay una diferencia de tiempo.

A lo largo de la primera parte del cuento, a través del juego con las perspectivas, la escritura desmantela los mecanismos ficcionales del cine; la mirada desengañada de Ernesto desvela en cada momento "la discontinuidad que contradice la tendencia hacia lo continuo de la que se alimenta la impresión de realidad"12 que el cine quiere producir.

11 M. Pezzella, op. cit., p. 41.

12 J.-L. Comolli, op. cit., p. 95. 
En este sentido, el cuento está construido sobre un mecanismo de espejos también entre la historia y la articulación del discurso; la representación en la pantalla que los personajes del relato perciben, y remiten al lector dentro de la historia, parece adherirse a los planteamientos del cine espectacular, mientras que el discurso textual remite más bien a una estructura que reflejaría los del cine crítico-expresivo ${ }^{13}$.

La articulación de una focalización cambiante permite representar un shock de segundo grado entre la identificación con las imágenes de la pantalla -simbolizada por el miedo que Claudia advierte- y la conciencia de su carácter artificial -encarnada en la actitud irónica de Ernesto-, shock que reproduce las dinámicas de la fruición cinematográfica. Ernesto mira sin ser visto, triunfa como sujeto en la visión de un objeto disponible por completo, lo cual parece anular cada residuo de alteridad y consagrar su superioridad.

\section{Del “LAdo DE Allá”}

Las categorías fundamentales implicadas en la elaboración del concepto de mirada desde la perspectiva del sujeto implican las relaciones entre visión, identidad y saber; la subjetividad se relaciona con la otredad mediante una modalidad cognoscitiva vinculada a una toma de conciencia "visiva" a través de la mirada ${ }^{14}$. La mirada, además, es un presupuesto fundamental para el estar-en-el-mundo antes que para entenderlo, con lo cual, lejos de ser fruto de un proceso únicamente activo, se convierte en el centro de la acción que el sujeto sufre: "A cada momento, mientras nuestra mirada viaja a través del panorama estamos sometidos a cierto punto de vista" 15 .

Al mismo tiempo, los fenomenólogos han afirmado con precisión que se ve afuera, es decir, que la percepción no está en el sujeto, sino en los objetos que capta y, sin embargo, capta el mundo en una per-

13 El cine espectacular actúa como un desahogo en contra del imaginario psicótico de la modernidad; en lugar de reflejarlo, ese tipo de cine nos acostumbra a dicho imaginario. El cine crítico-expresivo, en cambio, deja emerger los delirios de la modernidad y utiliza una forma simbólica que permite su comprensión e integración. Se podría comparar con una especie de terapia colectiva en la que la humanidad intenta reconocer y modificar el carácter traumático de la experiencia.

14 Con respecto a los estudios sobre la constitución del yo, el cambio de rumbo se debe a las teorías lacanianas, que postulan que el proceso de construcción de la identidad se vincula al mecanismo del reflejo, descrito en el "El estadio del espejo" y profundizado en Cuatro conceptos fundamentales del psicoanálisis. El sujeto toma conciencia de sí y de su contexto en la imagen reflejada; es decir, el autoconocimiento y la percepción situacional se dan a través de una alteridad -la imagen reflejadaconocible mediante la mirada.

15 M. Merleau-Ponty, op. cit., p. 21. 
cepcíon que le restituye la sensación del "me veo verme" ${ }^{16}$. En este sentido, la percepción subjetiva se inserta en esta relación reflexiva bipolar, por la cual, en la medida en que el sujeto percibe, es percibido y sus representaciones no le pertenecen. Esta dinámica, sin embargo, no puede realizarse en el espacio del cine; éste es un lugar privilegiado porque allí el espectador es detentor de un poderío completo sobre la imagen en la pantalla, puesto que él puede ver a quienes no pueden devolverle la mirada. Dicho poderío se representa en la primera parte en la seguridad que Ernesto manifiesta ante la película que está mirando, así como en sus reflexiones que explicitan los medios del cine y el carácter ficticio de la película.

En la segunda parte del relato, la condición privilegiada de espectador del protagonista se trastoca, y a dicha subversión le corresponderá también una derrota inicial de la autoridad de su mirada. El término de la película que los personajes están viendo sanciona el comienzo de la segunda parte. En la segunda secuencia, propiamente de transición, Ernesto deja a Claudia en su casa y se dirige a su domicilio en San Ángel, donde se desarrolla la tercera secuencia. Al llegar a casa, de repente se desata una tormenta y se va la luz. El hombre se dirige hacia la cocina con un candelabro, y en ese momento:

...se dio cuenta de que el corredor era idéntico al de la película. No, idéntico no: era el mismo corredor de la película. La piel de Ernesto se erizó. Estaba en el corredor que había pisado siempre desde niño y también en el corredor en los Cárpatos... Se detuvo. Escuchó el aleteo de un murciélago. Cuando Ernesto se volvió el murciélago era ya el vampiro, el muerto vivo desenterrado en el siglo xvi y ahora mismo en 1961 y en el presente perpetuo que es el único tiempo conjugable en el cine.

La escena de la película descrita al inicio del relato, perteneciente al "mundo de celuloide" -mundo de ficción dentro de la ficción del relato-, ahora se reescribe y se actualiza en el mundo de Ernesto. El pasillo de su casa sigue siendo el corredor de su casa, pero ahora es también el del castillo en los Cárpatos que Ernesto acaba de ver en la película, lo que permite dar paso a que Ernesto venga a ocupar el lugar de la víctima de la película:

Ernesto arrojó el candelabro. Se apresuró a abrir la puerta de la cocina. Entró en ella y descubrió a dos mil o tres mil espectadores que contemplaban la película de la que Ernesto no saldrá jamás. Porque el vampiro ya clava en él sus colmillos y la mano de Claudia se aferraba a la mano de un Ernesto ficticio. El verdadero Ernesto, ya agonizante, puede mirarlo desde el otro lado de la pantalla mientras el vampiro le envenena la sangre y lo va hundiendo para siempre en la noche (p. 87).

${ }^{16}$ JacQues Lacan, Los cuatros conceptos..., p. 88. 
Este último párrafo del cuento resulta central puesto que sanciona el concepto según el cual la mirada, lejos de ser el fruto de un proceso únicamente activo, se convierte en el centro de una acción que el sujeto sufre antes de ejercer, en cuanto expuesto, parafraseando a Jacques Lacan, a una mirada que se le acerca y lo convierte primero en un ser mirado, pero sin que se le muestre ${ }^{17}$.

El desenlace viola por completo una de las prerrogativas del cine, es decir, el voyerismo absoluto que el medio cinematográfico confiere al espectador. Se rompe su invulnerabilidad; las imágenes y su fuerza ya no lo confirman en su rol centrípeto de sujeto omnividente, sino que lo atraen literalmente fuera de sí, hacia un punto que no coincide con las expectativas del yo.

El juego de miradas sobre el que se construye el texto hace que la confianza en la estabilidad del mundo se engañe y la claridad de la distinción entre lo real, lo visto y lo imaginario se haga difusa. Ante esta ambigüedad, la realidad que pasaba desapercibida se convierte en problemática, encontrándose así "presentificada" 18 , lo que contribuye a su fascinación. Al hacer esto, la literatura construye un espacio de acogida; allí no sólo lo indecible se balbucea, sino que la alteridad se presenta.

Dicha "presentificación” se realiza en el texto en algunos detalles que podrían pasar desapercibidos en una primera lectura, pero que es posible volver a leer a la luz del desenlace. La referencia final a un "Ernesto agonizante" remite a la inicial en que "la cara del hombre que representa a la víctima" en la pantalla "adquiere un aspecto de terror verdadero" (p. 85); mientras que la coincidencia entre el corredor de su casa y el de los Cárpatos que Ernesto había visto en la película (p. 87) reenvía al primer párrafo, a la familiaridad que el personaje siente ante las imágenes de la película: "En la pantalla observada por miles de personas... apareció un corredor sombrío... Ernesto debió haberla visto [la película] de niño, porque en ella todo le parecía familiar" (p. 85).

La coincidencia entre los dos corredores que Ernesto ve significa una yuxtaposición entre los dos mundos, lo que implica la superación del límite espacio-temporal, simbolizados en la pantalla como punto crítico, horizonte de no retorno. También la muerte como límite queda superada; a pesar de ser representada, y exorcizada, en las reflexiones del personaje sobre las técnicas del montaje, el personaje queda sujeto a un eterno retorno, a aquel "presente perpetuo que es el único tiempo conjugable en el cine" 19 . Se realiza, de este modo, aquella "ilusión

17 Ibid., p. 81.

18 Maurice J. Lefebvre, L'image fascinant et le surréel, Plon, Paris, 1965, p. 93.

19 José Emilio Pacheco, "Nota: La historia interminable”, en La Sangre de Medusa y otros cuentos marginales, Era, México, 1990, p. 87. 
de inmortalidad" a la que alude Horacio Quiroga con respecto a la imagen fílmica ${ }^{20}$.

La obra de arte cinematográfica se pone ante el protagonista espectador con el carácter multívoco y polivalente que caracteriza la obra de arte, "libre" de las conexiones de experiencia que suscita, por la asociación libre que promueve. La película se hace sugeridora simbólicamente de posibilidades de experimentación moral o cognoscitiva, razón que explica el desencadenamiento de interpretaciones -críticas en este caso- en la recepción por parte del personaje. Al mismo tiempo, sin embargo, la apertura de la obra de arte atrae al personaje en una fruición interpretativa que lo aprisiona en la obra misma. Si el receptor se recrea activamente en la obra y goza de ella, en ese caso es recreado pasivamente, atrapado en una cadena infinita de repeticiones y desdoblamientos de su vida que es la película, y de la película que es su vida.

\section{DE LOS DOS LADOS}

La escritura literaria de "No perdura" se articula sobre una constante utilización del lenguaje fílmico y otra tanta deconstrucción de sus prerrogativas más importantes. En este sentido, la puesta en escena de lo que acontece en los dos lados de la pantalla hace que el discurso se construya sobre un principio de "coexpresividad"21 entre las reflexiones que destruyen cada falsa impresión de mimetismo de la que Ernesto estaba convencido al principio, y el fondo onírico, pregramatical de la imagen en la que el personaje se encuentra cautivo.

A dicha coexpresividad le corresponde, a lo largo de la historia, el despliegue de una imagen cada vez más "dialéctica" -término utilizado por Walter Benjamin y por Theodor Adorno en un ámbito histórico y estético, y retomado por Pezzella en el ámbito cinematográfico ${ }^{22}$; ; es decir, una imagen que hace visible la presencia simultánea de fuerzas antagónicas, sin reducirlas a una armonía fingida y sin privilegiar la una sobre la otra. La imagen dialéctica se sintetiza en la afirmación siguiente: "el vampiro ya clava en él sus colmillos y la mano de Claudia se aferraba a la mano de un Ernesto ficticio" (p. 87). Esa escena condensa a la vez, ante la mirada de los lectores, lo que pasa dentro de la pantalla y en la sala de cine, imagen que sella la definitiva superación del límite espacio-temporal representado por la pantalla en el instante mismo de su transgresión. Representar la superación de los límites de la representación implica representar aquello que por definición

${ }^{20}$ Horacio Quiroga, Cine y literatura, Losada, Buenos Aires, 2007, p. 287.

21 Erwin Panofsky, "Stile e mezzo nel cinema".

${ }^{22}$ M. Pezzella, op. cit., p. 78. 
es irrepresentable: una proposición paradójica que atenta contra el orden establecido por el límite.

En esta línea, el relato se apropia de la dualidad que caracteriza las imágenes del cine, dualidad que se refleja en el cuento, por un lado, en la reversibilidad de las situaciones y de los puntos de vista y, por el otro, en la irreversibilidad del movimiento. Al mismo tiempo, el cuento acaba borrando aquel "desnivel temporal" que se encuentra entre imagen y objeto representado o, mejor dicho, acaba distorsionándolo, puesto que esta diferencia deja de existir para el personaje una vez superada la pantalla, horizonte de no retorno que desencadena una serie de repeticiones infinitas.

La referencia al "Ernesto ficticio", además, remite a la dinámica descrita por Jacques Lacan en "El estadio del espejo" (1949), donde, al mirarse en el espejo, el sujeto se ve a sí mismo trasladado en una "línea de ficción" y se descubre como alteridad inalcanzable e inabarcable $^{23}$. La articulación de las líneas del dispositivo narrativo alude a un sofisticado juego de espejos, puesto que "realidad" y ficción exceden sus límites para aflorar la una en el territorio de la otra, revelando el carácter "real" de lo antes considerado ficticio por Ernesto, a la vez que pone en tela de juicio la sustancia misma de su "realidad". El texto pone en escena la relación biunívoca que se da entre la fragmentación del sujeto que observa y produce el discurso, y la pérdida de autenticidad del espacio a partir del cual mira -que se revela ficticio-y del objeto que observa, que al final se revela real. El sujeto que mira se transforma en el objeto observado, con lo cual de detentor del control se transforma en víctima del mismo ${ }^{24}$.

Utilizando el cine como espacio simbólico, el texto plantea de qué manera la idea de mirada interactúa con el concepto de sujeto a partir y dentro de la espacialidad en la que éste está inserto. A la importancia del poder de la mirada subjetiva, por lo tanto, se añade la reflexión sobre la conformación del sujeto como un ser que antes de mirar es mirado, configurándose como el que Lacan define "speculum mundi" 25 . Siguiendo la fenomenología de la percepción de Maurice MerleauPonty, según Lacan, el ojo no es sino la metáfora de algo que más bien podría llamarse "el brote del vidente, algo anterior a su ojo", con lo cual se hace necesario deslindar la preexistencia de una mirada a la que el

23 Jacques Lacan, "El estadio del espejo", p. 87.

24 Es importante señalar, aunque sea de paso, que el juego de espejos que se articula en el relato se extiende también a la ironía que el protagonista manifiesta hacia la película en la primera parte, ya que ésta se refleja en la ironía que subyace en toda la narración, visible en el contraste que existe entre la actitud del personaje Ernesto al principio del argumento y el trastocamiento que lo envuelve al final.

25 JacQues LACAN, Cuantros conceptos..., p. 81. 
ser humano está sometido de manera originaria: "sólo veo desde un punto, pero en mi existencia soy mirado desde todas partes" ${ }^{26}$.

En el cuento, la historia se convierte en simple sostén de una constelación simbólica y visual, en algo secundario con respecto al valor de las imágenes y de su fuerza expresiva, una "compañera de camino" en palabras de Roland Barthes. En este sentido, la escritura parece movida por una tendencia crítica y deconstructiva que pretende desmitificar la desmitificación, puesto que el protagonista acaba convirtiéndose, o revelándose, en lo que él mismo desenmascaraba, es decir, una "ilusión de realidad".

\section{LA PANTALLA COMO ESCAPARATE: ENTRE EXHIBICIÓN Y TRANSFIGURACIÓN}

El trastocamiento de las relaciones de poder que el cambio de la mirada conlleva se complica si se tiene en cuenta el saberse vinculado a ella. José Emilio Pacheco no se limita a reproducir en el cuento la llamada estructura de "cajas chinas", sino que vuelve aún más complejo ese mecanismo. Lo que se produce no es simplemente una reciprocidad de la mirada, sino más bien el doblarse de la mirada sobre sí misma y una puesta en duda de la ontología misma de la "realidad" y de los límites de cada ficción.

La diferencia sustancial que se da entre las dos partes del relato radica en la conciencia que el protagonista o, mejor dicho, los dos Ernestos tienen de su mirada. Dos elementos están en juego: la mirada y su interiorización. En la primera parte, Ernesto está convencido de la superioridad de su mirada crítica sobre la película, es más, todo acontece en la ignorancia de los que están involucrados en el juego de la vista. En la segunda, en cambio, el personaje se descubre dentro de la película que él mismo estaba mirando, lo cual le permite reparar en la mirada del público y del "otro" Ernesto sobre sí; es esta toma de conciencia lo que permite que la relación de poder se mantenga. Al mismo tiempo, al cruzar la pantalla, aunque víctima de la acción que se desarrolla en la película, Ernesto acaba siendo el único que llega al conocimiento de relaciones subterráneas y silenciadas que se establecen dentro del espacio del cine entre espectadores y personajes de la película, así como de la borrosidad de los límites entre "realidad" y ficción. Si el ejercicio del poder se juega precisamente en el hecho de que el sujeto perciba la mirada ajena sobre sí pero no pueda mirar a su vez, en el relato el poderío que la mirada otorga es efectivo en ambos casos pero, al mismo tiempo, engañoso. 
Desde su butaca en el cine, Ernesto cree estar en una condición de superioridad con respecto a lo que mira, porque no sabe-todavíaque él también está involucrado en el juego de miradas que pretende dominar, siendo mirado a su vez. Encontrarse del "lado de allá" y descubrir la mirada del público y del "otro" Ernesto sobre sí, significa acceder al conocimiento de relaciones distorsionadas e ignoradas por los demás. Al cruzar la pantalla, el personaje no es solamente víctima, sino que también es el detentor de un poder por el hecho de haber llegado a una sabiduría de la que los otros quedan excluidos; sin embargo, no está en condición de ejercer el poderío que procede de dicho saber, porque no puede abarcar todo quedándose invisible a quienes observan, sino que sufre la mirada de los otros del lado de allá. El cuento aborda las problemáticas de la mirada en sus dos desarrollos opuestos, al llevar al extremo la posibilidad de su poder, así como de su fracaso, en la figura de Ernesto dentro de la película -sujeto que percibe y se sabe percibido-, a la vez que subraya también el desconocimiento que la puede fundar a través de su condición fuera de la película. Totalidad y parcialidad de la mirada se encuentran representadas en la condición doble del protagonista.

En el centro del relato no hay una coherencia sistemática fruto de un "ego" unificado y estable, sino una incoherencia asentada en la idea de que el "yo" es más que uno. La vacilación que el personaje tiene al principio del relato acerca de la familiaridad de la escena que ve en la pantalla podría constituir una brecha en su conciencia y, por lo tanto, en el texto mismo, hacia la realidad extratextual, en cuanto devolvería al personaje la intuición, enseguida reprimida, de su esencia fingida. En este sentido, la imagen observada por Ernesto en la pantalla constituye una reverberación de su misma sustancia y anticipa su revelación final, vinculadas ambas a una ignorada ficción.

Frente a sujetos unitarios se pone en escena un sujeto en proceso, y se sugiere las posibilidades de otros innumerables sujetos, de historias distintas, donde hay cambios continuos de perspectiva en una sucesión vertiginosa de puntos de vista. La mirada desdoblada del protagonista lo revela ante el lector como "un ser que ni es enteramente nadie ni enteramente deja de ser alguien" 27 ; se trata de una existencia a medias, no por incompleta, sino por desdoblada en dos mitades que se unen con esa inquietud última que queda siempre tras una fisura a punto de abrirse.

Dicha existencia a medias parece vincularse a la problemática relativa al papel y a la raíz de la imaginación individual que Italo Calvino

27 Me apropio aquí de las palabras que Pere Gimferrer utiliza para describir a la protagonista de la película Persona, en el análisis que aparece en Cine y literatura, Planeta, Barcelona, 1985, p. 34. 
denomina la "cultura de la imagen prefabricada" en sus "lecciones americanas" en la Universidad de Harvard:

Una volta la memoria visiva dell'individuo era limitata al patrimonio delle sue esperienze dirette e a un ridotto repertorio d'immagini riflesse nella cultura; la possibilità di dar forma a miti personali nasceva dal modo in cui i frammenti di questa memoria si combinavano tra loro in accostamenti inattesi e suggestivi. Oggi siamo bombardati da una tale quantità di immagini da non saper più distinguere l'esperienza diretta da ciò che abbiamo visto per pochi secondi alla televisione ${ }^{28}$.

La vida del protagonista resulta exhibida en un escaparate diario, espectacular, creado y determinado por agentes poderosos que se quedan oscuros. La vida, igual que el arte, se muestra como un laboratorio artificial, en donde se estiliza hasta lo esencial de lo cotidiano, que sin perder su radical carácter familiar, revela acentos y matices distintos, un abanico de posibilidades que están ahí, pero que debe ser mostrado a través de una adecuada esencialización artística ${ }^{29}$. Como la obra artística verdadera, el cuento de Pacheco transfigura lo cotidiano desde lo cotidiano que es plasmado y conservado: revela y patentiza lo que subsiste y late en él de singularidad callada y muda; da expresión, palabra, imagen verbal, a esa mudez forzada y, de este modo, el relato se inscribe dentro de una poética de resistencia a la compartimentación que produce estructuras que categorizan la experiencia.

\section{REPRESENTACIÓN Y CUESTIONAMIENTO}

En "No perdura”, José Emilio Pacheco explora y explota la potencialidad mimética de la imagen fílmica, una de las artes analógicas por excelencia, como afirma Roland Barthes, y convierte el universo ficcional de la película en un mundo "real", consistente y paralelo al de los personajes. Al mismo tiempo, sin embargo, al colocar al protagonista del otro lado de la pantalla, el autor perturba las relaciones de poder y saber vinculadas al concepto de mirada en el cine, y desvela y subraya el régimen ficticio del personaje mismo, así como de su realidad.

La escritura parece dotada de ese potencial subversivo que Rosmary Jackson atribuye a los relatos fantásticos; ofrece una inversión de la unidad que se encuentra en lo fantástico moderno, puesto que representa un orden cultural desestabilizado sin recurrir "a otros mundos compensatorios y trascendentales" ${ }^{30}$. Mediante su negativa a

28 Italo Calvino, Lezioni americane, Mondadori, Milán, 2009, p. 103.

29 Cf. Eugenio Trías, Filosofía del futuro, p. 111.

30 Rosemary Jackson, Fantasy, literatura y subversión, Catálogos, Buenos Aires, 1986, p. 151. 
constituir categorías, el texto tiene una colocación paraxial que erosiona los pilares de la sociedad, erosión en la que late una resistencia ante tal reducción.

Modulando las miradas, el autor juega con el concepto de la recíproca permeabilidad de visión y conocimiento, y no pone en escena realidades alternativas, sino que construye dos mundos vacíos y vaciantes que se vierten el uno en el otro y se disuelven a través de la pantalla. Su vacuidad vicia al mundo visible, pleno, esférico y tridimensional, al dibujar en él ausencias, sombras sin objetos. Tales espacios, en lugar de satisfacer el deseo, lo perpetúan, pues insisten en la ausencia, la carencia, lo no visto, lo que no puede verse ${ }^{31}$. Dicho trastocamiento elimina la oposición misma entre realidad y ficción, a la vez que problematiza la noción de realismo.

De este modo, a partir de la mirada del yo sobre el sujeto, el relato de Pacheco indaga los límites de lo real, aquel "continente negro"32 que impide una mirada hermenéutica unívoca y, al mismo tiempo, ensancha su margen convirtiéndolo de ámbito reducido en espacio privilegiado de articulación ficcional. La inversión axiológica implicada en dicha apertura conlleva la propuesta de que la costumbre de representar el mundo, que el crítico atribuye al relato "no fantástico", es decir, "de pretensión mimética", es una forma de ceguera; la realidad visible es una ilusión, y la ficción puede ser, por consiguiente, más real.

La ficción que Pacheco construye dentro del terreno literario -la película y la historia que la contiene- se sustenta en el cuestionamiento de la noción misma de realidad y tematiza el carácter ilusorio de todas las "evidencias", de todas las "verdades" transmitidas en que se apoya el hombre de nuestra época y de nuestra cultura ${ }^{33}$. En tal sentido, el texto se constituye como el producto de un desencuentro inefable entre la palabra y la cosa y plantea una pregunta hermenéutica. Se vuelve a problematizar la exhaustividad de la mirada como instrumento de conocimiento y la inteligibilidad última de lo real, con lo cual el discurso planteado parece estar en relación intertextual constante con ese otro discurso que es la realidad, entendida como construcción cultural $^{34}$.

El texto encarna un "modelo en conflicto" elaborado por el llamado "posmodernismo resistente" 35 , puesto que plantea una decons-

31 Ibid., p. 17.

32 Roger Bozzetto, “¿Un discurso de lo fantástico?”, en Teorías de lo fantástico, ed. D. Roas, Arco/Libros, Madrid, 1990, p. 242.

${ }^{33}$ Cf. Susana Reisz, "Las ficciones fantásticas y sus relaciones con otros tipos ficcionales", en Teorías de lo fantástico, ed. D. Roas, p. 194.

${ }^{34}$ Cf. Ricardo Reis, "O fantástico do poder e o poder do fantástico", Ideologies and Literature, 134 (1980), p. 6.

${ }^{35}$ El sintagma está presentado por HaL FosTER en la introducción a la recopilación de ensayos editados por él, La posmodernidad (p. 12). Se ofrece aquí la definición 
trucción crítica de la tradición, un cuestionamiento de los orígenes y de los códigos culturales, así como de los lenguajes estéticos. En particular, tanto la crítica socio-histórica como la exploración literaria que subyacen al relato ponen en escena una debilitación de la autenticidad de la experiencia y de la experiencia estética, y una crítica de la representación, a la vez que apuntan a una desestructuración del orden de las representaciones a fin de reinscribirlas. Se pone en tela de juicio la idea de que la experiencia estética existe separada, más allá de la historia, o de que el arte puede producir un mundo a la vez (inter) subjetivo, concreto y universal, una totalidad simbólica, y se sugiere una revisión también de la noción de estética como intersticio subversivo y crítico en un mundo por lo demás instrumental.

Si lo imposible se enfoca en un sistema que lo representa para deconstruir los presupuestos que lo gobiernan, y cuestiona directamente los preconceptos que ordenan su mundo para dejar en evidencia su insuficiencia ${ }^{36}$, a través de la representación verbal de algo imposible, José Emilio Pacheco captura la paradójica naturaleza del límite, definiéndolo negativamente, a través de una escritura que oscila constantemente entre las fronteras de la representación y el impulso de superarlas, y que atrapa al lector y al protagonista en el vértigo incesante de lo irrepresentable.

\section{Margherita Cannavacciuolo \\ Dipartimento di Studi Linguistici e Culturali Comparati Università Ca’'Foscari Venezia}

brindada por FREDERIC JAMENSON: “...no es sólo otra palabra para la descripción de un estilo particular. Es también... un concepto ¿periodizador? cuya función es la de combinar/relacionar la emergencia de nuevos rasgos formales en la cultura con la emergencia de un nuevo tipo de vida social y un nuevo orden económico..." ("Posmodernidad y sociedad de consumo", en La posmodernidad, ed. H. Foster, Kairós, Barcelona, 2008, p. 167).

36 Mario BoIDo, De límites y convergencias: la relación palabra/imagen en la cultura visual latinoamericana del siglo XX, Iberoamericana-Vervuert, Madrid-Frankfurt/M., 2012, p. 117. 
